\title{
POSITION OF THE CERTIFICATED AIR CARRIERS IN CIVIL AERONAUTICS BOARD FREIGHT PROCEEDINGS
}

\section{E. Smythe Gambrell* and Charles A. Moye, Jr. $\dagger$}

The nation's scheduled air transportation system is a public utility regulated by the Civil Aeronautics Board under the Civil Aeronautics Act of 1938 , as amended. ${ }^{1}$ It is composed of sixteen so-called trunkline air carriers and a number of so-called feederline air carriers. Each of these holds one or more certificates of public convenience and necessity, issued by the Civil Aeronautics Board, authorizing the scheduled common carriage of passengers, mail, and property ${ }^{2}$ (which includes air freight and $a i$ express $^{3}$ ).

There have been three proceedings recently before the Civil Aeronautics Board involving air freight. In two of these-the combined Air Freight case and BostonNew York-Atlanta-New Orleans case, and the Air Freight Forwarder case-the question of the need for additional air freight carriers was raised. In the former case fourteen applicants sought certificates of public convenience and necessity authorizing the direct carriage of air freight. The Air Freight Forwarder case involved ro5 applications by 78 different applicants to engage indirectly in air transportation as air freight forwarders ${ }^{4}$ or in the carriage of air express by utilizing the

* A.B. 1915, University of South Carolina; LL.B. 1922, Harvard University. General Counsel, Eastern Air Lines, Inc. Contributor to legal periodicals.

†A.B. 1939, J.D. I943, Emory University. Member of Georgia bar. In general practice with firm of Gambrell, Harlan \& Barwick, Atlanta, Georgia.

${ }^{1} 52$ STAT. 977 (1938), as amended, 60 STAт. 1352,49 U. S. C. $\$ \$ 40$ I-680 (I946).

2 Two carricrs are authorized to carry property and mail only, via helicopter in the vicinity of Los Angeles and of Chicago.

${ }^{3}$ In its decision in the combined Air Freight case, Docket 810, et al., and Boston-New York-AllantaNew Orleans case, Docket 730 et al., decided July 29, I949, the Board stated (p. 6 of mimeographed opinion):

"Accordingly, we hold as a matter of law, that any carrier authorized by its certificate to carry property is thereby authorized to carry any kind of property including baggage, express, and freight." The Board explained the difference between air freight and air express in its decision in the Air Freight Forwarder case, Docket 68I et al., decided September 8, I948, as follows (p. I6 of mimeographed opinion):

"The difference between air express and air freight lies principally in the ground and accessorial services provided and in the amount of the rates charged shippers for the respective services. Air freight is carried at rates usually less than half those assessed against air express."

"The Civil Acronautics Board defines air freight forwarders in terms of the same characteristics by which the Interstate Commerce Commission identifies surface forwarders (Air Freight Forwarder case, stipra, note 3, p. 35 of mimeographed opinion).

Part IV of the Interstate Commerce Act defines freight forwarders as follows:

"The term 'freight forwarder' means any person which (otherwise than as a carrier subject to Chapters 1,8 , or 12 of this title) holds itself out to the general public to transport or provide transportation of property, or any class or classes of property, for compensation, in interstate commerce, and which in the ordinary and usual course of its undertaking, (A) assembles and consolidates or provides for assembling and consolidating shipments of such property, and performs or provides for the performance of brcak-bulk and distributing operations with respect to such consolidated shipments, and 
aircraft operated by direct air carriers. The Board's decision in the Air FreightBoston-New York-Atlanta-New Orleans case granted certificates of public convenience and necessity authorizing the air transportation of property only (not including air express) to four of the applicants, Slick Airways, Inc., the Flying Tiger Line, Inc., U. S. Airlines, Inc., and Airnews, Inc.; the decision and order in the Air Freight Forwarder case established a regulation (known as Section 292.6 of the Board's Economic Regulations) exempting air freight forwarders from the certificate provisions of the Act and providing that letters of registration under that regulation be issued to certain applicants. 5

A third proceeding, the Air Freight Rate case, Docket 1705 et al., decided June 2, I948, involved the air freight rates to be charged by the direct carriers. The Board's decision in that case set the minimum rates which might be charged, but specifically permitted the carriers to file petitions for reconsideration seeking adjustments in such minimum rates. Two further proceedings have grown out of petitions for reconsideration so filed, one involving less-than-minimum directional commodity rates and the other involving rules of certain carriers providing for accumulation, assembly, and distribution services.

The cargo services of the certificated ${ }^{3}$ carriers are the result of years of experimentation and effort. Those services and the "know how" back of them are invaluable national assets. These carriers have, therefore, in each of the air freight proceedings mentioned above, constantly sought to impress upon the Board the vital necessity of an economically sound national air cargo system capable of providing for the public the maximum amount of air cargo service at the lowest possible rates. The relationship of this over-all position to each of the air freight proceedings mentioned above will be set out below.

\section{I}

\section{The AIR FreIGHT CASE $^{7}$}

As indicated above, this proceeding involved the requests of some fourteen applicants for authority to carry air freight only. The certificated carriers opposed the granting of these applications because:

(B) assumes responsibility for the transportation of such property from point of receipt to point of destination, and (C) utilizes, for the whole or any part of the transportation of such shipments, the services of a carrier or carriers subject to Chapters 1,8 , or 12 of this title." 56 STAT. 284 (1942), 49 U. S. C. $\$ 1002$ (1946).

Both of these cases are now on appeal. The Air Freight-Boston-New York-Atlanta-New Orleans case is on appeal in the Court of Appeals for the District of Columbia (the appeal of American Airlines, Inc., is docketed as case No. I0374, that of Transcontinental and Western Air, Inc., as case No. 10387, and that of Eastern Air Lines, Inc., as case No. 10388). The Air Freight Forsuarder case is on appeal in the Court of Appeals for the Seventh Circuit, case No. 9739.

"As used in this article the term "certificated carriers" will not include the applicants who received certificates or letters of registration as the result of the Board's decision in the Air Freight-Boston-New York-Atlanta-New Orleans case and the Air Freight Forwarder case.

This term will hereinafter be used to designate the combined Air Freight and Boston-New YorkAtlanta-New Orleans case, supra note 3. 
(x) The air freight services of the certificated carriers are adequate to meet the public need;

(2) The diversion from the certificated carriers of their cargo traffic would cause them serious injury;

(3) The applicants could not meet the statutory standards of fitness, willingness, and ability; ${ }^{8}$ and

(4) As a consequence of the above an economically unsound air cargo transportation system would be created through certification of the applicants.

The certificated carriers conceived and initiated the development of the air cargo business. During the late nineteen twenties and nineteen thirties most of the cargo transported by the airlines was air express. There were several efforts to establish air express service independent of the Railway Express Agency, ${ }^{9}$ but in 1935 all the airlines except Transcontinental and Western Air signed agreements with the Railway Express Agency, ${ }^{10}$ providing that the latter should handle air express on the ground. The rapid growth of air express from that time is indicated by the following table showing the yearly ton-miles of air express carried by all of the certificated airlines from 1935 through $194^{8: 11}$

\begin{tabular}{|c|c|c|c|}
\hline \multicolumn{4}{|c|}{ Yeardy Ton-Mires of Air Express } \\
\hline & $\ldots \ldots \ldots, \mathbf{1 , 0 8 9 , 8 0 2}$ & 1942 & $\mathrm{Ir}, 69 \mathrm{r}, 208$ \\
\hline & $\begin{array}{l}\mathrm{r}, 860,807 \\
\end{array}$ & 1943 & 15, II 7,925 \\
\hline 937 & $2,156,070$ & I944 & $17,488,432$ \\
\hline & $2,173,706$ & 1945 & $20,845,292$ \\
\hline & $2,705,6 \mathrm{x}_{4}$ & $x 946$ & $23,786,579$ \\
\hline & $3,469,485$ & x947 & $.28,533,362$ \\
\hline & - $5,242,529$ & 1948 & 29,768,883 \\
\hline
\end{tabular}

As indicated by the Civil Aeronautics Board's definition, ${ }^{12}$ air express is just one form of air cargo. The entire history of air transportation has been one of progressively converting to air carriage traffic which formerly had moved only by surface transportation. Air cargo transportation is no exception to the rule. In the early development of air cargo transportation only cargo urgently needed at destination moved by air. This cargo was ideally suited to air express carriage which received expedited handling both in the air and on the ground. However, as air service is daily becoming a more accepted mode of passenger transportation for

${ }^{8}$ Section $4^{0 r}(\mathrm{~d})(\mathrm{I})$ of the Civil Aeronautics Act provides:

"The Board shall issue a certificate authorizing the whole or any part of the transportation covered by the application, if it finds that the applicant is fit, willing, and able to perform such transportation properly, and to conform to the provisions of this Chapter and the rules, regulations, and requirements of the Board hereunder, and that such transportation is required by the public convenience and necessity; otherwise such application shall be denied." 52. STAT. 987 (1938), 49 U. S. C. $\$ 481$ (d)(I) (r946).

${ }^{\circ}$ See John H. Frederick, Commerictal Air Transportation, c. 21 (1946).

${ }^{10}$ Transcontinental and Western Air signed up with the Railway Express Agency on September I, 1937.

${ }_{11}$ FrEDERICK, op. cit. supra note 9, at 531; Form 2780 and Form 41 Reports submitted by airlines to Civil Aeronautics Board.

${ }^{12}$ Sec note 3 , supra. 
people who have never flown before, so it is becoming the accepted mode of transportation for an ever wider variety of cargo.

The greatest stimulus to the mass use of air cargo transportation came from World War II. Out of the unrelenting need for fast and reliable transportation in support of the national war effort grew new techniques and greater familiarity with the immense possibilities of air cargo transportation. Probably the most important contribution of the war to the civil air cargo industry, however, was the greatly increased public acceptance of this war-glorified transportation medium because of the large amount of publicity which it daily received.

Unfortunately, the certificated airlines were in no position to capitalize on these new developments immediately after the war. Under military necessity they had patriotically surrendered a large part of their equipment, in some cases more than half of the entire fleet of an individual carrier, to the armed forces. Air carrier contracts for the purchase of new equipment had been assigned in toto to the Government. The remaining equipment was insufficient to handle even priority traffic (priority air cargo as well as priority passengers). Low priorities were "bumped" by high priorities and high priorities by higher. Even the return of some flying equipment to the certificated air carriers during the closing days of the war did not enable them to catch up with the flood of emergency traffic.

Despite the lack of equipment with which to handle the traffic, the certificated air carriers sought to prepare as soundly as possible for the expected great future growth of air cargo transportation. Air Cargo, Inc., was set up by four of the major airlines ${ }^{13}$ for the purpose of providing the research foundation necessary to the later expansion of air cargo facilities. ${ }^{14}$ Some carriers were operating schedules

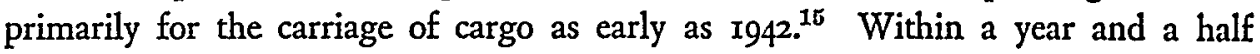
following the close of the war all but one of the certificated trunkline carriers had filed tariffs covering the general transportation of air cargo, some of these being filed as early as $1944 .^{16}$

Today the certificated carriers operate a comprehensive air cargo transportation system. Nine of the sixteen trunkline carriers operate all-cargo equipment in addition to combination equipment also carrying passengers and mail. ${ }^{17}$ All of the certificated carriers, both trunkline and feeder, carry air cargo, including, of course, air freight, on equipment which also carries passengers and mail. ${ }^{18}$ Concerning the present pattern of air freight service provided by the certificated carriers the Civil Aeronautics Board stated: ${ }^{19}$

\footnotetext{
${ }^{1 s}$ American Airlines, Inc., Eastern Air Lines, Inc., Transcontinental and Western Air, Inc., and United Air Lines, Inc. Other certificated air carriers later joined in this organization.

${ }^{11}$ FREDERICK, op. cit. supra note 9, at 565-573.

${ }^{15}$ Testimony of Paul H. Brattain, First Vice-President of Eastern Air Lines, Inc., in Air Freight case, supra note 3 .

${ }^{16}$ Brief of Air Transport Association of America to Examiner dated April 14, 1947, p. 35, in Air Freight case, stipra note 3 .

17 Air Freight case, supra note 3, p. 25 of mimeographed opinion.

${ }^{28}$ Id. at 17.

10 Id. at 25-26.
} 
Among the certificated carriers who operate all-cargo planes a logical pattern of service is emerging which provides for regular schedules of all-cargo aircraft to major route points only. The normal volume traffic demands of lesser intermediate points are met by utilization of combination aircraft. Where occasional traffic at these points exceeds the capacity of the combination schedules, then an effort is made to accommodate the traffic by adding the point as a stop on an all-cargo flight. This pattern of service, expanded as required by traffic increases, is that which will be afforded by the multipleservice carriers in the foreseeable future and appears to be a sound and logical expansion from a passenger, mail, and express service.

The certificated carriers provide all-cargo service to every major cargo-generating center of the United States. The volume of cargo service they provide to every city is fully sufficient for its needs. Following is an analysis submitted to the Civil Aeronautics Board in the Air Freight case showing by quarters the amount of freight carried by the certificated carriers during the four-year period I945-I948 and the volume of surplus capacity which could have been utilized for the carriage of cargo had such cargo been available. ${ }^{20}$

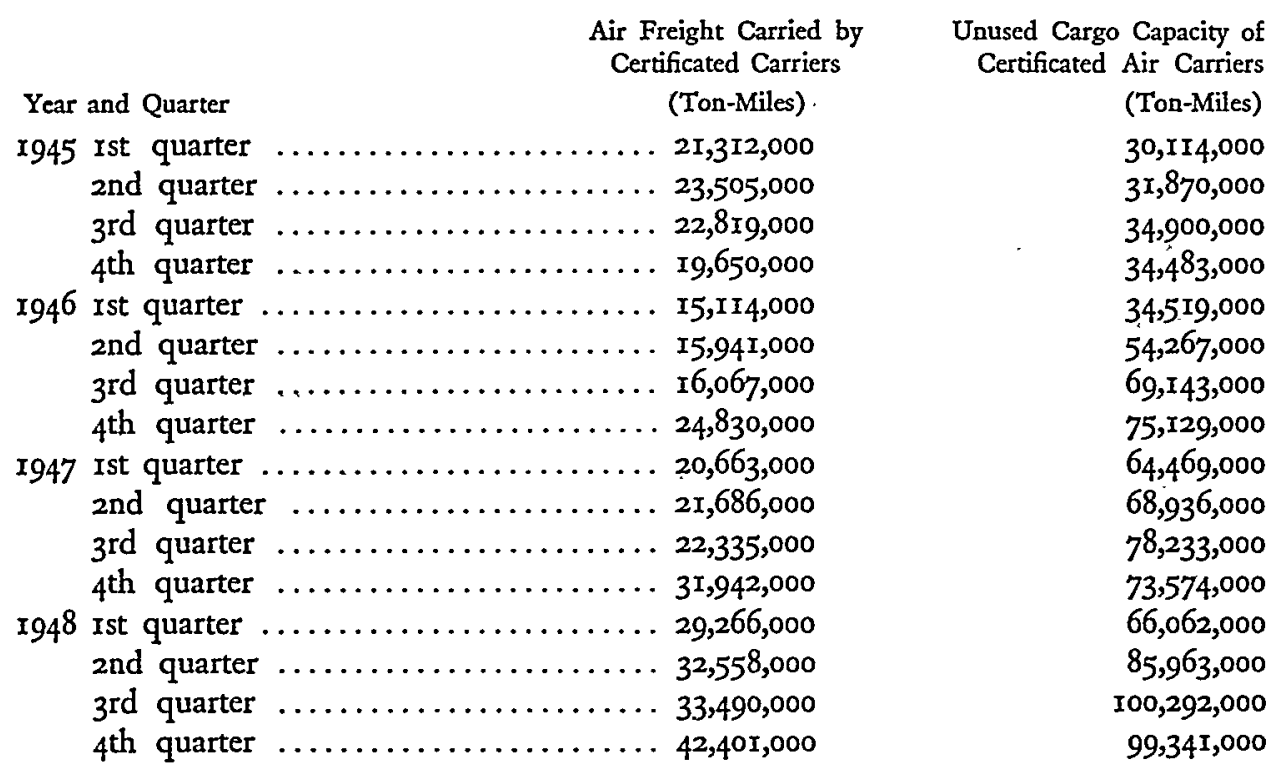

In view of the completeness of the air cargo services of the certificated carriers, as indicated above, the consideration of the need for additional cargo-only carriers raises immediately two questions: (I) Is there sufficient cargo traffic economically to support additional cargo-only carriers; and (2) will such carriers provide the public any needed new service? It is the position of the certificated carriers that neither of these questions can be answered affirmatively.

Several of the applicants in the Air Freight case have been operating for over two years as scheduled common carriers of air freight under an extraordinary ex-

${ }^{20}$ Exceptions on Behalf of American Airlines, Inc., to the tentative Opinion of a Majority of the Board, dated May 19, 1949, Appendix II. 
emption (Section 292.5 of the Board's Economic Regulations) from the certificate provisions of the Civil Aeronautics Act. ${ }^{21}$ Data as to these operations were made of record at a reopened hearing of the Air Freight case in November and December of r948. Each of the freight-only carriers which took advantage of the Board's exemption order incurred losses running into millions of dollars. ${ }^{22}$ These losses cannot be blamed on uneconomical equipment for these carriers were operating all types of equipment (C-47's, $\mathrm{C}_{-4} 6 \mathrm{~s}^{\mathrm{s}}$, and $\mathrm{C}_{-54} \mathrm{~s}$ ). It is obvious that such enormous transportar tion operating losses would not have been incurred had there been available sufficient cargo traffic to support additional carriers economically.

The applicants premised their contention that there is sufficient cargo traffic to support additional cargo carriers upon various forecasts placed in the record of the Air Freight case before any operating experience under Section 292.5 of the Board's Regulations had been accumulated. The Board's analysis, in its Air Freight case opinion, of the nation's air freight potential similarly is grounded upon "paper" forecasts ${ }^{23}$ and also upon an analysis of air freight rates as compared with surface transportation rates. ${ }^{24}$ In the opinion of the certificated carriers, the actual operating results of the certificated carriers and the applicants are more to be trusted in assessing the national reservoir of air freight potential than the untested conjectural calculations of even the most competent experts.

Furthermore, even if there should be sufficient cargo traffic potential to support additional carriers, that fact would not necessarily mean that such additional carriers should be certificated. In the Chicago-Milwaukee-New York case the Board stated: $:^{25}$

The mere fact that a particular route develops a large volume of traffic does not of itself afford sufficient justification for a finding that the public convenience and necessity require establishment of an additional competitive service exactly duplicating an existing operation.

The property-only carriers would not provide air cargo service for additional cities which are not now receiving such service. The record in the Air Freight case shows that they have concentrated their service at only a few relatively large cities. U. S. Airlines' reports to the Board show that practically all of its service is between New York and Atlanta, with occasional service to Miami. The reports of the Flying Tiger Line show that it has served regularly only the following cities: Chicago, Cleveland, Detroit, Kansas City, Los Angeles, New York, Philadelphia, San Francisco, and St. Louis. Similarly the reports of Slick Airways show regular service at the following cities only: Los Angeles, San Francisco, Chicago, Dallas,

${ }^{2 x}$ Section 295 (formerly 292.5) of the Economic Regulations of the Civil Aeronautics Board.

${ }^{23}$ Special Reports filed by non-certificated cargo carrier applicants on April 15, 1948, and Regular Reports filed by the same carriers pursuant to Section 242 (formerly 202.1) of the Board's Economic Regulations.

${ }^{23}$ Air Freight case, supra note 3, p. 12 of mimeographed opinion.

${ }^{24} I d$. at $\times 3-22$.

${ }^{25} 6 \mathrm{CAB} 217,228$ (1944). 
Detroit, Houston, New York, Philadelphia, St. Louis, and San Antonio. Most of the above cities receive multiple all-cargo schedules from one or more of the certificated carriers. ${ }^{26}$

The property-only applicants at one time contended that they would provide cargo service for numerous small cities under a novel concept of common carriage which they labeled "area" or "demand point" service. This theory of service involved the furnishing of regularly scheduled service at a few large "principal" points and service at smaller cities or "demand" points only if a volume of traffic meeting large minimum tender requirements (usually 500 to 2,000 pounds) should be available. It should be mentioned again at this point that the property-only applicants have been operating for over two years as scheduled common carriers of air freight with much greater freedom from regulatory obligations and restrictions than if certificated, and in addition they undoubtedly have been striving to prove their case for certificates. Yet Slick Airways, for example, during the seventeen-month period August I947 through December I948 made only thirty-nine stops at "demand" points, and the Flying Tiger Line none. The certificated carriers, of course, have always provided cargo service at such smaller cities either through the use of the cargo space available on combination equipment, or through the use of all-cargo equipment where necessary. ${ }^{27}$ The actions of the property-only carriers following certification reveal their determination not to provide service at the "smaller" cities. Thus, Slick has filed airport notices stating its intention to serve Wilmington, Delaware, a city of II2,000, through the Philadelphia airport, and Akron, Ohio, a city of 250,000 , through the Cleveland airport. U. S. Airlines similarly proposes to serve Belle Glade, Florida, a city which the property-only applicants asserted has a substantial cargo potential, through the West Palm Beach airport which already receives cargo service by the certificated carriers.

In providing demand point service, the property-only carriers would rely on commission agents to perform their solicitation, cargo handling, etc. ${ }^{28}$ The certificated carriers, from years of experience, know that such a set-up will not provide satisfactory service for the public and is not consistent with the high public responsibility attaching to common carriage.

The authorization of property-only carriers can lead only to more expensive air freight service for the public. A former chairman of the Board has stated: ${ }^{29}$

I am quite certain that an adequate air operation transporting mail only would be more expensive and would require greater mail payments than does the present system of conducting air operations on a mail, passenger and property basis.

This ability of the certificated carriers to render a more economical air freight service

so Airline Traffic Guides.

${ }^{27}$ See note 19, sttpra.

${ }^{23}$ Report of Examiners William F. Cusick and R. Vernon Radeliffe, served March 12, 1948, p. 248, Air Freight case, stupra note 3.

${ }^{20}$ Statement of James M. Landis to the subcommittee of the House Post Office and Civil Service Committec on December I2, 1947 . 
than property-only carriers, and consequently to give lower rates to the public, was recognized by the Examiners: $:^{30}$

Certainly the public convenience and necessity is best served by the operation that will give the needed service at the lowest cost consistent with reliability and safety. In many past cases involving the selection of a carrier for extension over a new route segment the Board has considered, among other things, the additional initial and operating expenses of the various applicants in maintaining such a service. Thus, an applicant who already had sales and operations personnel located in the points to be joined by a new routing could show less added expense in those categories than the carrier who would be required to set up facilities at those points. As between applications, the Board has considered that one might be able to serve the new route by increasing the utilization of equipment owned, whereas another would have to add new planes for the purpose. Such considerations, of course, imply something short of full utilization of personnel and equipment in a given operation, but do not detract from the practical force of the considerations. Without attempting to fix the traffic volume points at which additional station personnel become necessary, it has been recognized that additional units of traffic can generally be handled at less cost than similar initial traffic.

Because of their existing extensive organizations, the certificated airlines are in position to handle air cargo at much less additional cost than the applicants. The validity of this "share-the-cost" concept is not dependent upon having cargo move in the same planes as passengers and mail. Wherever a battery cart, or a wheel chock, or the president of the company, can be shared between the cargo service and the service required for other classes of traffic, the multiple service carrier necessarily is able to offer the public a cheaper and more economical service than the carrier whose single class of traffic must support all expenses. This saving can and will be passed on to the public in the form of reduced rates unless arbitrarily prevented by governmental action to protect less economical carriers.

The authorization of cargo-only carriers will cause a serious and wasteful diversion of needed traffic from the certificated carriers. The Examiners found: $:^{31}$

The total amount of competitive air service contemplated by the proposals in this proceeding appears to far surpass that of any case previously before the Board.

The President's Air Policy Commission stated $:^{32}$

In regard to the first issue (spreading air cargo among more lines than now exist as common carriers) as we have said above, most common carrier air lines certificated for the carriage of passengers, property, and mail, after a steady progression toward selfsufficiency from 1938 to 1946 have suffered a serious set-back. Our major problem is to get them started once again up the ladder toward self-sufficiency. To advocate at this time the entry into this field of a large number of new carriers would certainly seem to postpone rather than hasten the attainment of such a state.

${ }^{30}$ Examiners' Report, supra note 28, at 243-244.

${ }^{31} I d$. at 240.

32 Survival in the Alr Age, A Report by the President's Air Policy Commission ir3-i14 (January $r, 1948$ ). 
The certificated carriers certainly are not champions of monopoly. They recognize that the spectacular growth of the industry has been due in large measure to the ever-present stimulus of competition. But it is impossible to conceive of the present air transportation industry as resembling a monopoly in any degree. There are twenty-eight airlines now operating domestically, not counting the property-only carriers. Practically all major routings are served by two or more carriers. Each of these airlines provides air freight service to the extent of the public demand for such service. An industry consisting of twenty-eight air cargo carriers is a far cry from a monopoly.

If at some future time the air freight market develops to such proportions that it cannot adequately be handled by the existing carriers, the Board might very properly give consideration to the authorization of additional carriers. That time is not yet here. The size of the air freight market is problematical, and it would be an unwarranted gamble to authorize cargo-only carriers at this time.

The certificated carriers believe that the applicants in the Air Freight case are not qualified to undertake the extensive new services for which four of them have been authorized. The large operating losses of the applicants have already been noted. $^{33}$ U.S. Airlines, for example, has incurred total expenses of approximately 80 cents per ton-mile for every ton-mile of air freight carried by $\mathrm{it}^{34}$ and yet it could not expect to charge the public more than 20 cents per ton-mile for the carriage of such freight. During only two and a half years of operations, U. S. Airlines exhausted about five-sixths of its entire original capitalization of over three million dollars, a total loss of $\$ 2,557,93^{3.35}$ Slick Airways during nearly two and threequarters years of exempted operations exhausted about six-sevenths of its capitalization, a total loss of $\$ \mathrm{r}, 93 \mathrm{r}, 242,{ }^{36}$ and the Flying Tiger Line, in three and a half years of operations, well over one-half of its capitalization, a total loss of approximately $\$ \mathrm{I}, 350,000 .^{37}$ These facts are far from convincing that the all-cargo carriers are "fit, willing and able" successfully to operate the extensive systems for which they have been certificated. They have managed to keep going only through engaging in outside activities such as aircraft maintenance. ${ }^{38}$ Ability to secure such outside revenues furnishes no proof as to fitness, willingness, and ability to conduct an air cargo transportation system.

On the basis of the above factors, and others which cannot be discussed because of space limitations, it has seemed clear to the certificated carriers that the applications in the Air Freight case ought to have been denied.

\footnotetext{
${ }^{33}$ See note 22 , supro.

${ }^{34}$ U. S. Airlines' Special Reports and Section 202.I Reports, note 22, stipra.

${ }^{35}$ Ibid.

${ }^{30}$ Slick Airways' Special Reports and Section 202.I Reports, note 22, supra.

${ }^{37}$ Flying Tiger Line's Special Reports and Section 202.I Reports, note 22, supra.

${ }^{38}$ Air Freight case, supra note 3, p. 2 I of mimeographed opinion.
} 
II

\section{The Aur Freight Forwarder Case}

As indicated above, this proceeding involves numerous applications to engage indirectly in air transportation as freight forwarders. ${ }^{39}$ In Universal Air Freight Corporation-Investigation of Forwarding Activities ${ }^{40}$ and in Railway Express Agency, Inc., Certificate of Public Convenience and Necessity, ${ }^{41}$ the Board held that one who engages in forwarding activities is an air carrier within the meaning of Section I(2) 42 of the Civil Aeronautics Act. In the Universal case the application of Universal Air Freight Corporation for an exemption under Section $I$ (2) was denied, and, until the Board's decision of September 8, 1949, there were no legally operating common carrier air freight forwarders (other than the Railway Express Agency whose air express activities were approved by the Board in Railway Express Agreements). ${ }^{43}$

These applications in the Air Freight Forwarder case were opposed by the certificated carriers in line with their broad general policy of advocating the maintenance of the soundest possible air transportation system. There are two fundamental bases for this opposition: (I) because of the physical nature of air transportation, there is no public need for air freight forwarding as might be contended in relation to surface transportation agencies, and (2) the practice of forwarding is so fraught with opportunities for abuse that it should not be introduced into the air transportation industry without an impelling public need.

Freight forwarding had its origin in certain deficiencies inherent in the transportation of freight by railroad. The only carrying unit in railroad freight transportation is the boxcar with capacities ranging from 3,000 to 4,800 cubic feet and a weight of around 50 tons. ${ }^{44}$ The less-than-carload freight which the railroads carry averages only about 400 pounds per shipment in weight and originates and terminates in thousands of different stations. ${ }^{45}$ Because of the above factors which have prevented high equipment utilization at reasonably high load factors, ${ }^{48}$ the railroads have offered numerous inducements to the less-than-carload shipper, such as free loading and unloading, pickup and delivery, etc., the costs of which have combined to cause the railroads to suffer a loss of $\$ 7.53$ per ton on less-than-carload freight as against a substantial profit on carload traffic. ${ }^{47}$

${ }^{80}$ See definition of freight forwarders, note 4 , supra.

${ }^{10} 3 \mathrm{CAB} 698$ (1942). $\quad{ }^{21} 2 \mathrm{CAB} 53 \mathrm{I}$ (1941).

4 Section $x(2)$ provides:

"Air Carrier' means any citizen of the United States who undertakes, whether dircetly or indirectly or by a lease or any other arrangement, to engage in air transportation: Provided, That the Board may by order relieve air carriers who are not directly engaged in the operation of aircraft in air transportation from the provisions of this Chapter to the extent and for such periods as may be in the public interest." 60 STAT. 1352, 49 U. S. C. $\$ 401$ (2) (1946).

${ }_{43}^{4}$ CAB 157 (1943).

" Testimony of Jervis Langdon, Vice-President of Air Cargo, Inc., in Air Freight Forsvarder case, supra note 3 .

${ }^{45}$ Ibid.

${ }^{40} \mathrm{~A}$ term used to signify the traffic/capacity relationship.

${ }^{4}$ Freight Forwarding Investigation, 229 I. C. C. 201, 3II (1238). 
The surface forwarders thus found a natural "vacuum" ready for their operations. By taking the railroads' unprofitable less-than-carload traffic and turning it back to them in the form of profitable carload traffic, the forwarders contend that they perform a service beneficial to the railroads. Because of the large rate spreads due to the large cost differentials in handling carload as against less-than-carload traffic, the forwarders say that they have been able to perform this service at no extra cost to the shipper, and, because of certain desirable characteristics of carload as against less-than-carload shipments (such as more direct and speedy movement ${ }^{48}$ ), actually have provided a service superior to that which the railroads alone could provide.

Much the same situation exists in the field of motor transportation although a large part of the use by forwarders of motor carriers for line-haul transportation seems to result from the fact that they have been able to exact very favorable terms from motor carriers through special contracts and joint rates. ${ }^{49}$

The air transportation industry is not a suitable one into which to transplant the freight forwarders. Less-than-planeload traffic does not cost the air carriers more to handle than does planeload traffic. ${ }^{\overline{0}}$ The cargo capacity of combination aircraft is composed of several carrying units of different size. Small shipments receive the same routine expedited attention which planeload shipments receive. The certificated carriers load and unload all shipments, large and small, as an airplane cannot economically be parked on a side-track, and therefore must be unloaded promptly by the air carrier's employees. Because of the lack of cost differentials, there could be no justifiable rate differentials in favor of large shipments which could be passed on to shippers. ${ }^{51}$ The forwarders could not improve upon the procedures of the certificated carriers in the handling of air freight in such matters as the tracing of shipments and the handling of claims as they assert they have improved on procedures in surface transportation. ${ }^{52}$

In view of the lack of public benefit which would result from the certification of air freight forwarders, it appears unsound to introduce into the air transportation field the myriad abuses which have resulted from forwarding activities in surface transportation, and other abuses which would be made possible because of the special characteristics of air freight transportation.

By consolidating small shipments into large, and securing the cheaper rate applicable to the latter, the forwarder in some instances may, if he wishes, offer the public rates which are cheaper than those of the direct carrier. The forwarder thus is able to build up a volume of traffic which it controls and may use this traffic as bait to induce competing direct carriers to offer more attractive rates or more

${ }^{18}$ Air Transport Association Exhibit 74, p. 5, in Air Freight Forwarder case, supra note 3.

${ }^{10}$ C. Allen Elggren, What Part Should Freight Forwarders Have in the Development of the Air Freight Industry? I4 J. AIR L. AND CoMr. x70, 184-188 (1947); Freight Forwarder-Motor Common Carriers, Agreements, Docket 29493-I. C. C.

${ }^{50}$ Testimony of Paul H. Brattain, First Vice-President of Eastern Air Lines, Inc., pp. W. 2772, 3, 4, $6-7,8 ;$ W. 2814 , of transcript of oral testimony in Air Freight Forwarder case, supra note 3.

${ }^{6 x} I d$. at W. 99 and W. $1028-29$.

"Id. at W. $2763-2767$. 
service to the forwarder. The record in the Air Freight Forwarder case contains a lengthy catalogue of the illegal concessions which the surface forwarders were able through their traffic "club" to exact from the surface carriers: $:^{53}$ the furnishing of space and other facilities at less than cost; ${ }^{54}$ preference in size of box cars; ${ }^{65}$ lower charges for loading and unloading service; ${ }^{56}$ permission to stop cars in transit under conditions other than those provided in the tariff; ${ }^{57}$ expedited train and switching services ${ }^{38}$ and credit in violation of effective regulations. ${ }^{69}$ The Interstate Commerce Commission has recognized the serious nature of the problem of abuses by forwarders, and has stated: ${ }^{60}$

This proceeding demonstrates that any railroad refusing the demands of the forwarders would summarily sacrifice the traffic to another railroad, unless, of course, the railroads in general should combine in their efforts, and that is exactly what they have refrained from doing for fear of losing their individual prestige with a particular forwarder. There is doubt whether any legislation of this character designed to regulate the forwarder, as a shipper, could be enacted to avoid abuses even more grave than those under the present law.

The certificated air carriers, interested in the sound and wholesome development of the air transportation industry, are fearful of the undesirable practices which might be introduced into air transportation through the certification of air freight forwarders. The Board's statement, ${ }^{61}$ "... . we believe that even should a forwarder attempt such practices we will, pursuant to our powers under the Act, be able to prevent the harmful results that the direct carriers fear," offers scant comfort to the certificated carriers. Abuses of the sort mentioned above are insidious in, character, because they involve the forced cooperation of the direct carriers, and would require constant vigilance on the part of the Board. The Board's inability to police even flagrant violations of the Act, because of lack of manpower, has been strikingly demonstrated in the wholesale violations of the certificate provisions of the Act by the so-called "non-scheduled" carriers. In the opinion of the certificated carriers the puny or non-existent benefits which the forwarders might offer air transportation are not worth such an exorbitant price.

\section{III}

\section{The Air Freight Rate Case}

Throughout the various air freight proceedings before the Board the Air Freight case applicants have argued in favor of their certification on the ground that they would provide lower air freight rates than the certificated carriers. They established air freight rates producing an average return of 13.29 cents per ton-mile despite the fact that they were losing money rapidly in doing so. ${ }^{62}$

${ }^{53}$ See discussion in Section II(B) of Brief of Air Transport Association to Civil Acronautics Board, dated May 26, 1948, in Air Freight Forwarder case, supra note 3.

${ }^{54}$ Freight Forwarding Investigation, 229 I. C. C. 201,217 (1938).

${ }^{65}$ Id. at 231 .

${ }^{58}$ Id. at 263 .

${ }^{50}$ Id. at 237.

${ }^{50}$ Id. at $264-265$.

${ }^{67}$ Id. at 250-251.

${ }^{00}$ Id. at 303 .

o2 Air Freight Forwarder case, supra note 3, p. 47 of mimeographed opinion.

${ }^{03}$ Air Freight Rate case, Brief of Public Counsel dated March 22, 1948, p. 15. 
The certificated carriers filed on August I, I947, a consolidated air freight rate tariff providing a yield of approximately 20 cents per ton-mile between I00 and I,200 pounds, and scaling down to $I_{4}$ cents per ton-mile for 16,000 pounds and over. ${ }^{63}$ Later some certificated carriers filed specific and all-commodity rates which proposed a yield of approximately 13 cents per ton-mile. ${ }^{64}$ The Board suspended these proposed tariffs and entered into a general investigation of the air freight tariffs of all carriers, certificated and non-certificated. ${ }^{65}$ This investigation was known as the Air Freight Rate case.

The two primary questions involved in the Air Freight Rate case were: (I) whether there should be a minimum rate order, and (2) whether the Board should require volume breaks ${ }^{66}$ in air freight tariffs. The certificated carriers took the position that no minimum rates should be established by the Board, and that, because of the physical nature of air transportation, volume breaks are not justified. The Board in its decision in the Air Freight Rate case, however, did issue a minimum rate order providing minimum rates of $x 6$ cents per ton-mile on the first I,000 ton-miles of any shipment and I3 cents on all ton-miles in excess of 1,000 , thus incorporating volume breaks in its order.

It should be pointed out that the Air Freight Rate case arose, in part, upon the complaint of the non-certificated Air Freight case applicants. ${ }^{67}$ It appeared that these applicants, although they preached loudly the benefits of competition in their quest for certificates, were afraid of equal competition in actual practice. Concerning this situation the Board stated: $:^{68}$

When the uncertificated carriers sought and were granted the right to compete on a scheduled common carrier basis with the certificated carriers, they asked and received the right to compete. They filed tariffs generally some 30 per cent below those of the certificated carriers. The certificated carriers in return filed tariffs on a selected list of commodities between selected points some 4 per cent below those of the uncertificated carriers. On other commodities, and other weights, and between other points, their old tariffs remained. Admittedly this is competition, even though it may not be competition at every point. But unless this be unfair competition, this is the very privilege that the uncertificated carriers asked and were granted. The exemption accorded them certainly was not that of a one-sided right, namely the right to compete against the certificated carriers and the privilege to be protected against competition from them.

As has been pointed out above, because of their ability to spread numerous expenses among their freight and other services, the certificated carriers naturally can provide lower air freight rates than all-cargo carriers whose entire expenses must be charged to their freight services. The non-certificated carriers during the course of the Air Freight Rate case attempted to discount this obvious advantage of the cer-

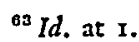

- Id. at 2.

is Board Order Serial No. E-I0I6, dated November 24, I947.

${ }^{\circ 0}$ Rates that reduce at intervals according to the weight of the shipment.

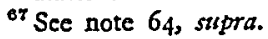

${ }^{08}$ Motions of Air Freight Forwarder Association, et al., 8 CAB 469, 472 (1947). 
tificated carriers by artificial allocation theories in which they advocated an equal ton-mile allocation of all expenses between freight and other services even though such allocation would load the freight services with expenses not attributable thereto. They attacked the validity of basing air freight rates on the maximum gross return possible over out-of-pocket costs, even though this is a sound rate making principle, employed and sanctioned for years in surface transportation. ${ }^{60}$ They adopted the ostrich-like view condemned by Locklin: ${ }^{70}$

There is a school of thought, however, which believes that overhead costs should be allocated to particular kinds and units of traffic and that all rates should be based on these allocations. The advocates of this view maintain that cost accounting has developed into a science and that practically all costs can be allocated. This view seems to rest upon a failure to understand the economic principles involved. It is true that all costs can be allocated, but as one writer has expressed it, "that fact of itself is no more significant than is the possibility of obtaining an arithmetical average of any fortuitous collection of numbers."

The Board's decision in the Air Freight Rate case unfortunately turned apparently on the Board's desire to protect the non-certificated carriers from the competition which they had advocated, despite its prior utterances in the Motions of the Air Freight Forwarder Association, et al. ${ }^{\text {I }}$

The Directional Commodity Rate case is an outgrowth of the Air Freight Rate case, which was left open to petitions for reconsideration and modification of the minimum rate order therein established. ${ }^{72}$ Several petitions proposing less-thanminimum directional commodity rates have been filed, a hearing has been held, and briefs to the Board have been filed. In general, it is the position of the certificated carriers that there should be more reliance upon sales effort to correct the problem of directional unbalance of traffic, rather than upon the panacea of directional rates. The all-cargo carriers, reversing their previous stand on the out-of-pocket cost concept, fervently espouse widespread application of extremely low directional commodity rates.

As appears from the above brief résumé of several proceedings, the air cargo transportation industry is dynamic. Our hope is that the Civil Aeronautics Board will give its growth sound direction and not permit it to develop the defects which have characterized other transportation enterprises.

${ }^{80}$ David P. Locklin, Economics of Transportation, c. 7 (I947).

${ }^{70} \mathrm{Id}$. at $157-158$.

71 Air Freight Rate case, pp. 5-6 of Tentative Opinion, dated April 2x, 1948.

79 Order Serial No. E-1639, dated June 2, 1948, p. 3. 